\title{
Prevalence of Shiga Toxin-Producing and Enteropathogenic Escherichia coli in Wild and Pet Birds in Iran
}

\section{-Author(s)}

\section{Koochakzadeh $\mathrm{A}^{\prime}$}

Askari Badouei M"

Zahraei Salehi T'

Aghasharif S"I

Soltani Miv

Ehsan MRIV

Department of Microbiology, Faculty of Veterinary Medicine, University of Tehran, Tehran, Iran

" Department of Pathobiology, Faculty of Veterinary Medicine, Garmsar Branch, Islamic Azad University, Garmsar, Iran

II Faculty of Veterinary Medicine, Garmsar Branch, Islamic Azad University, Garmsar, Iran

iv Department of Poultry Diseases, Faculty of Veterinary Medicine, University of Tehran, Tehran, Iran

\section{-Mail Address}

Corresponding author e-mail address Mahdi Askari Badouei

Department of Pathobiology , Faculty of Veterinary Medicine, Garmsar Branch, Islamic Azad University, Garmsar, Iran. Postal Code: 3581631167

Tel.: +98-2324252121

Fax: +98-2324252020

Email: mic.consult@gmail.com askari@iau-garmsar.ac.ir

\section{- Keywords}

EPEC, STEC, stx2f, pet birds, wild birds

\section{ABSTRACT}

The aim of this study was to investigate the prevalence of Shiga toxin-producing Escherichia coli (STEC) and enteropathogenic E. coli (EPEC) strains and to identify the stx gene types in wild captive and companion birds. In total,657 E. coli isolates from 219 birds belonging to 38 different species were investigated for the presence of STEC and EPEC strains. It was shown that five birds (2.28\%) carried strains positive for one or more of the virulence factors investigated. The results indicated that $1.8 \%(n=4)$ and $0.45 \%(n=1)$ of the birds carried STEC and EPEC strains, respectively. All STEC strains harbored the stx $2 f$ and eae genes and this finding reveals the role of other birds, in addition to pigeons, as reservoirs of STEC. The only EPEC strain in this study was isolated from a Myna. Based on our knowledge, this is the first report of Stx2f-producing STEC in Geese, Duck and Lesser kestrel. In conclusion, the results indicate a low frequency of STEC carriage in wild and companion birds, and point out the need of additionally screening for the presence of stx $2 f$ in all the eae-harboring strains from birds.

\section{INTRODUCTION}

Escherichia coli belongs to the intestinal bacterial flora in most animal species. Although most $E$. coli strains are nonpathogenic, some strains may cause diarrhea and other intestinal diseases (Law, 1988). For instance, enteropathogenic $E$. coli (EPEC) have been considered as one of the most important strains that cause diarrhea in humans (Norazah et al., 1998). EPEC strains may express the outer membrane protein intimin (94-97 KDa), which is encoded by the eae gene and causes the attaching and effacing lesions in the epithelial cells of the intestine and resulting diarrhea in humans (Adu-Bobie et al., 1998). Some studies have shown the carriage of EPEC strains in birds (Kobayashi et al., 2009; Oh et al., 2011).

Shiga toxin-producing Escherichia coli strains (STEC) harbor Shiga toxin (stx) genes (Kobayashi et al., 2002) and are also able to cause diarrhea in humans and some animal species. They are linked to hemorrhagic colitis (HC), hemolytic uremic syndrome (HUS) and thrombotic thrombocytopenic purpura (TTP) in humans, which require hospitalization and intensive care with considerable mortality in children and elderly patients (Gyles, 2007). The ability of STEC strains to cause serious diseases in humans is related to the production of one or more Shiga toxins (Stx1, Stx2, or their variants), which inhibit protein synthesis in host cells leading to cellular damage (O'Brien et al., 1992).

While ruminants are the main reservoir of STEC, other domestic animals such as cats, dogs and pigs may also carry STEC and EPEC strains (Beutin et al., 1995; Zahraei Salehi et al., 2011). Moreover, some studies have also investigated STEC strains in wild birds and poultry in different countries (Kobayashi et al., 2002; Schmidt et al., 2000; 
Koochakzadeh A, Askari Badouei M, Zahraei Salehi T, Aghasharif S, Soltani M, Ehsan MR
Prevalence of Shiga Toxin-Producing and Enteropathogenic Escherichia coli in Wild and Pet Birds in Iran
Morabito et al., 2001; Ghanbarpour et al., 2011). More recently, a new subtype of stx, called stx $2 f$, has been described in STEC in pigeons (Schmidt et al., 2000). Strains harboring the st $2 f$ gene have been considered as emerging pathogens (Prager et al., 2009). Various methods have been applied for identification of STEC strains in birds, but most of them were unable to target the stx2f subtype (Askari Badouei et al., 2014; Ziebell et al., 2002; Feng et al., 2011).

Due to the wide geographical distribution, migratory habits, and the great diversity of avian species, the role of different bird species in carriage of eae and stx possessing Escherichia coli is poorly understood. Nevertheless, most birds, including pet birds, domestic fowl, and even raptors kept by humans may be potential unnoticed reservoirs of these enteric pathogens. To our knowledge, there are no studies on the prevalence and molecular characteristics of STEC and EPEC strains derived from pet and wild birds in Iran. Therefore, the aim of this study was to assess the role of birds as STEC and EPEC reservoirs in Iran.

\section{MATERIALS AND METHODS}

\section{Sample collection and culture}

A total number of 219 birds belonging to 38 different species were sampled in pet shops, zoological parks (Saei park) and birds referred to veterinary clinics (Table 1). The samples were collected from fresh droppings, or directly from the cloacae, using sterile swabs (Table 1). The samples were transported in Amies transport media (BBL, USA) to the laboratory and immediately streaked on MacConkey agar (Merck, Germany). After overnight incubation at $37^{\circ} \mathrm{C}$, up to four well-separated lactose-fermenting colonies were picked from each plate. The confirmation of the suspected isolates was performed by biochemical tests, including conventional lactose and glucose fermentation (using TSI medium), urease, indol, methyl red, Voges Proskauer, citrate and lysine decarboxylase (Quinn et al., 2011).

\section{DNA extraction}

Isolates confirmed as E. coli were sub-cultured on LB Agar. After an $18-20$ hours incubation at $37^{\circ} \mathrm{C}$, DNA was extracted of the strains by boiling method, as described previously (Zahraei Salehi et al., 2007).

\section{Screening PCRs for eae and stx}

The presence of the eae gene was screened using SK1 and SK2 general primers (Table 2; Schmidt et al., 1994). The PCR protocol was conducted using 2.5 $\mu \mathrm{L} 10 \mathrm{X}$ PCR buffer, $2 \mathrm{mM} \mathrm{MgCl}, 0.2 \mathrm{mM}$ dNTP, 1 unit Taq DNA polymerase enzyme (Cinnagen, Iran), $0.4 \mu \mathrm{M}$ of each primer working stock and $2 \mu \mathrm{L}$ boiled lysate as template DNA. Molecular grade distilled water was added to make the final volume of $25 \mu \mathrm{L}$.

In order to detect STEC strains, Lin-F and Lin-R primers (Table 2 ) that can detect all stx subtypes and variants, were used (Ziebell et al., 2002; Lin et al., 1993). Each PCR reaction included: $2.5 \mu L 10 X$ PCR buffer; $1.6 \mathrm{mM} \mathrm{MgCl}$; $0.2 \mathrm{mM}$ dNTP; 1 unit Taq DNA polymerase enzyme; $0.4 \mu \mathrm{M}$ of each primer; $3 \mu \mathrm{L}$ DNA; and ultrapure water up to $25 \mu \mathrm{L}$ (Table 2).

Amplification cycles for both protocols are summarized in Table 2. Positive control (E. coli O157:H7 Isolate No. 295) and negative control (sterile water) were included in all PCR reactions. To observe results, the PCR products were visualized on $1.2 \%$ agarose gel after electrophoresis and staining with ethidium bromide.

\section{Multiplex-PCR for stx1, stx2, eae, Ehly}

All stx harboring $E$. coli isolates were further screened by a multiplex-PCR using four pairs of specific primers (Table 2) for stx1, stx2, eae and Ehly as described by Paton and Paton (1998). Amplification was carried out in a total volume of $25 \mu \mathrm{L}$ containing: $2 \mu \mathrm{L}$ DNA; $0.3 \mu \mathrm{M}$ of each oligonucleotide primer; $0.2 \mathrm{mM}$ dNTP mix; $2 \mathrm{mM} \mathrm{MgCl} \mathrm{MM}_{2}$; $2.5 \mu \mathrm{L}$ of $10 \mathrm{X}$ PCR buffer; 1 unit Taq DNA polymerase (Cinnagen, Iran); and PCR grade water up to $25 \mu \mathrm{L}$. Samples were subjected to 35 cycles of touchdown PCR (Table 2) according to Paton and Paton (1998). The PCR products were submitted to electrophoresis on $2 \%$ agarose gels and visualized by staining with ethidium bromide. Positive PCR reactions were recorded by comparing the specific bands with 100bp-plus molecular size marker (Fermentas, Lithuania). Positive controls and negative controls (sterile water) were included in all PCR reactions.

\section{stx2f gene detection}

In order to detect stx $2 f$ gene in stx positive strains that yielded negative result in Multiplex-PCR, another $P C R$ was conducted with stx2fF and st $2 f R$ primers (Table 2) as described previously (Schmidt et al., 2000). Each PCR reaction included: $2.5 \mu \mathrm{L} 10 \mathrm{X}$ PCR buffer; $1.5 \mathrm{mM} \mathrm{MgCl} ; 0.2 \mathrm{mM}$ dNTP; 1 unit Taq DNA polymerase; $3 \mu \mathrm{L}$ DNA; $0.1 \mu \mathrm{M}$ of each primers; and molecular grade water. The applied thermal cycles are summarized in Table 2. T5b-Ir strain (Accession number KJ397538) was used as positive control. 
Table 1- Fecal samples obtained from various birds in Iran assessed for the presence of Escherichia coli harboring eae and stx genes.

\begin{tabular}{|c|c|c|c|c|}
\hline Bird (Common Name) & Bird (Scientific name) & $\begin{array}{l}\text { No. of } \\
\text { samples } \\
\text { tested }\end{array}$ & $\begin{array}{c}\text { No. of } \\
\text { eae-positive } \\
\text { isolates }\end{array}$ & $\begin{array}{l}\text { No. of } \\
\text { stx-positive } \\
\text { isolates }\end{array}$ \\
\hline Sulphur-crested Cockatoo & Cacatua galerita & 2 & & \\
\hline Green-winged Macaw & Ara chloropterus & 1 & & \\
\hline Lesser Kestrel & Falco naumanni & 7 & 1 & 1 \\
\hline Alexandrian Parrot & Psittacula eupatria & 1 & & \\
\hline Eurasian Eagle-Owl & Bubo bubo & 1 & & \\
\hline Fischer's Lovebird & Agapornis fischeri & 3 & & \\
\hline Chukar Partridge & Alectoris chukar & 5 & & \\
\hline African Grey Parrot (AGP) & Psittacus erithacus & 18 & & \\
\hline Pet Chicken & Gallus gallusdomesticus & 8 & & \\
\hline Common Buzzard & Buteo buteo & 1 & & \\
\hline Common Myna or Indian Myna & Acridotheres tristis & 34 & 1 & \\
\hline White-eared Bulbul & Pycnonotusleucotis & 2 & & \\
\hline Domestic Canary & Serinuscanariadomestica & 2 & & \\
\hline Common Magpie & Pica pica & 2 & & \\
\hline Budgerigar & Melopsittacus undulatus & 3 & & \\
\hline Blue and Yellow (Gold) Macaw & Ara ararauna & 1 & & \\
\hline Eastern Rosella & Platycercus eximius & 1 & & \\
\hline Cockatiel & Nymphicus hollandicus & 1 & & \\
\hline Domestic Duck & Anas platyrhynchos domesticus & 30 & 1 & 1 \\
\hline Domestic Pigeon & Columba liviadomestica & 6 & & \\
\hline Hooded Crow & Corvus cornix & 8 & & \\
\hline Saker Falcon & Falco cherrug & 1 & & \\
\hline Steppe Eagle & Aquila nipalensis & 2 & & \\
\hline Eurasian Sparrowhawk & Accipiter nisus & 2 & & \\
\hline Eurasian Woodcock & Scolopax rusticola & 1 & & \\
\hline Caspian Gull & Larus cachinnanas & 1 & & \\
\hline Orange-winged Amazon & Amazona amazonica & 1 & & \\
\hline Scaly-breasted Lorikeet & Trichoglossus chlor lepidotus & 1 & & \\
\hline Helmeted Guinea Fowl & Numida meleagris & 2 & & \\
\hline Muscovy Duck & Cairina moschata & 5 & & \\
\hline Common Pheasant & Phasianus colchicus & 7 & & \\
\hline Black Swan & Cygnus atratus & 2 & & \\
\hline Blue Peafowl & Pavo cristatus & 4 & & \\
\hline Japanese Quail & Coturnix japonica & 1 & & \\
\hline Ring-necked Parakeet & Psittacula krameri & 31 & & \\
\hline Domestic goose & Anser anser domesticus & 21 & 2 & 2 \\
\hline Total & & 219 & 5 & 4 \\
\hline
\end{tabular}

\section{RESULTS}

Among the 657 E. coli isolates investigated for the presence of the eae gene, five isolates, which were originated from five different birds belonging to four different species, resulted positive (Figure 1; Table 1). In screening PCRs for stx, four birds belonging to three different species carried STEC strains. The evaluation of the STEC isolates using a multiplex PCR for stx 1 , stx2, eae, Ehly only yielded the eae amplicon, but not stx 1 and/or stx2. All of these strains were shown to be positive for stx2f as demonstrated using the specific primers (Figure 1). In fact, except for one isolate, all eae-harboring isolates were STEC and carried stx $2 f$ gene. In total, five birds (2.28\%) carried strains positive for one or more of the virulence factors tested. Four E. coli strains were isolated from four birds belonging to three different species including (goose, duck and lesser kestrel) harbored both $s t \times 2 f$ and eae genes, while one isolate obtained from a Myna harbored only the eae (Figure 1; Table 1). 

Zahraei Salehi T, Aghasharif S, Soltani M, Ehsan MR
Koochakzadeh A, Askari Badouei M,

Prevalence of Shiga Toxin-Producing and Enteropathogenic Escherichia coli in Wild and Pet Birds in Iran

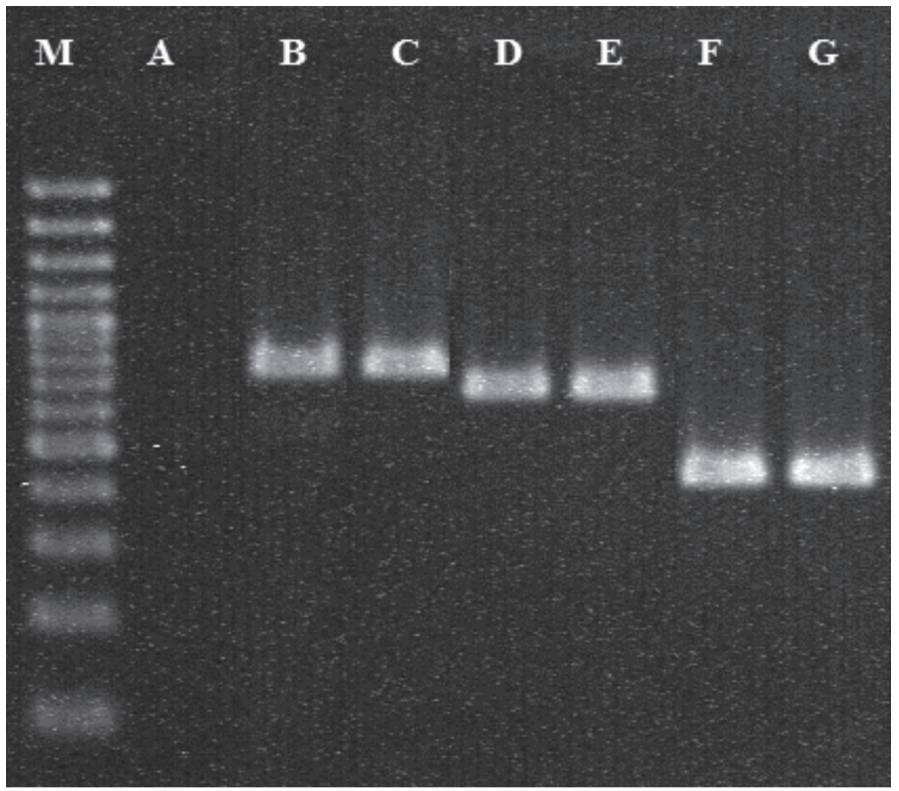

Figure1 - Different PCR assays for the detection of eae, stx and stx2f genes. M) Marker 100bp. A) Negative control. B) Positive control for stx gene (900bp) (E. coli 0157:H7, Isolate No. 295).C) One of stxpositive strains isolated in this study. D) Positive control for eae gene (863bp) (E. coli 0157:H7, Isolate No. 295). E) One of the eae positive strains isolated in this study. F) Positive control for stx2f gene (428bp) (T5b-Ir strain, accession number KJ397538).G) One of stx2f-positive strains isolated in this study.

\section{DISCUSSION}

The result of the current study showed a low prevalence of STEC in wild and pet birds in Iran. The prevalence of STEC has been investigated in different bird species in other geographical regions. Farooq et al. (2009) found $5 \%$ and $1 \%$ of $E$. coli strains positive for stx 1 and stx 2 in pigeons, respectively. In broilers, the stx2 gene was detected in $4.5 \%$ of the isolates in Iran (Ghanbarpour et al., 2011). On the other hand, some studies found no Shiga toxin genes in E.coli strains from poultry (Wani et al., 2004; Farooq et al., 2009). Similarly, stx 1 or stx 2 genes were not detected in E. coli from wild birds (Kobayashi et al., 2009), which is in agreement with the findings of the present study. As reported previously (Zeibell et al., 2002), the multiplex-PCR was not able to identify st $2 f$ subtype in the mentioned study.

In our study, the combination of stx $2 f$ and eae genes were detected in $E$. coli strains isolated from four birds (1.8\%) belonging to three different species. In general, pigeons are known as natural reservoirs of stx2f-harboring STEC strains (Kobayashi et al., 2002; Schmidt et al., 2000; Kobayashi et al., 2009; Askari

Table 2 - PCR primers and conditions for the amplification of stx and eae genes in this study.

\begin{tabular}{|c|c|c|c|}
\hline Name & Primer Sequence $\left(5^{\prime}\right.$ to $\left.3^{\prime}\right)$ & $\begin{array}{l}\text { Target Amplification condition } \\
\text { Gene }\end{array}$ & $\begin{array}{l}\text { Amplicon reference } \\
\text { Size (bp) }\end{array}$ \\
\hline
\end{tabular}

SK1 CCCGAATTCGGCACAAGCATAAGC

SK2 CCCGGATCCGTCTCGCCAGTATTCG

Lin-F GAACGAAATAATTTATATGT

Lin-R TTTGATTGTTACAGTCAT

StX1-F ATAAATCGCCATTCGTTGACTAC

Stx1-R AGAACGCCCACTGAGATCATC

Stx2-F GGCACTGTCTGAAACTGCTCC

Stx2-R TCGCCAGTTATCTGACATTCTG

Eae-F GACCCGGCACAAGCATAAGC

Eae-R CCACCTGCAGCAACAAGAGG

Hly-F GCATCATCAAGCGTACGTTCC

Hly-R AATGAGCCAAGCTGGTTAAGCT eae

$94^{\circ} \mathrm{C} 30 \mathrm{~s} ; 52^{\circ} \mathrm{C} 60 \mathrm{~s} ; 72^{\circ} \mathrm{C} 60 \mathrm{~s}$ (30 cycles)

stx

$94^{\circ} \mathrm{C} 30 \mathrm{~s} ; 45^{\circ} \mathrm{C} 60 \mathrm{~s} ; 72^{\circ} \mathrm{C} 60 \mathrm{~s}$ (33 cycles)

stx1

stx2

$95^{\circ} \mathrm{C} 60 \mathrm{~s} ; 65^{\circ} \mathrm{C} 120 \mathrm{~s} ; 72^{\circ} \mathrm{C} 60$ s (first 10 cycles) decreasing to $60^{\circ} \mathrm{C}$ (cycles 10-15)

$95^{\circ} \mathrm{C} 60 \mathrm{~s} ; 60^{\circ} \mathrm{C} 120 \mathrm{~s} ; 72^{\circ} \mathrm{C}$ 90s (cycles $15-25$ )

$95^{\circ} \mathrm{C} 60 \mathrm{~s} ; 60^{\circ} \mathrm{C} 120 \mathrm{~s} ; 72^{\circ} \mathrm{C} 150$ s (cycles $25-35$ )

eae

384

Ehly
Schmidt et al. (1994)

Lin et al. (1993)

180 
Koochakzadeh A, Askari Badouei M, Zahraei Salehi T, Aghasharif S, Soltani M, Ehsan MR
Prevalence of Shiga Toxin-Producing and Enteropathogenic Escherichia coli in Wild and Pet Birds in Iran
Badouei et al., 2014). The prevalence of stx $2 f+$ strains reported in pigeons ranged from 4\% to $18.8 \%$ in different studies (Askari Badouei et al.,2014; Schmidt et al., 2000; Farooq et al.,2009). Additionally, Wen-Jie et al. (2008) study showed the presence of stx2f gene in avian pathogenic E. coli (APEC) strains in China. Similar to our observation, previous studies showed that stx2f-harboring strains lack other stx subtypes and mostly possess the eae gene (Askari Badouei et al., 2014; Schmidt et al., 2000; Morabito et al., 2001). The strains possessing the stx2fleae genes in this study isolated from a duck, two geese and a lesser kestrel. Previously, eae+/stx2f+E. coli strains were detected in barn swallows in Japan (Kobayashi et al., 2009). However, the low prevalence of st $2 \mathrm{f}$-harboring STEC in the current and previous studies suggests that these strains are only part of the transient gut microflora. In this sense, wild and pet birds may have a minor epidemiologic role in comparison with Columbiformes as carriers of st $x 2 f+/ e a e+E$. coli.

In the present study, only one EPEC strain was identified. Faroog et al. (2009) concluded that all of the ducks and chickens sampled in their study were reservoirs of EPEC strains, while in another study only $8.7 \%$ of the birds harbored EPEC strains (Kobayashi et al., 2009).

According to the results of the present study, wild and pet birds may carry STEC and EPEC strains. Although all STEC strains in this study only possessed the st $2 f$ subtype, the public health significance of these strains should not be overlooked, because the stx $2 f+E$. coli strains have also been isolated from humans with diarrhea (Prager et al., 2009; Isobe et al., 2004). Recent evidences also show the particular importance of stx $2 f$ STEC as an emerging unnoticed human pathogen (Friesema et al., 2014). Since the stx2f is not easily identified using most routine diagnostic procedures (except using appropriate general primers), all of the eae-harboring strains from birds should be checked for the presence of this particular Shiga toxin subtype. Additionally, the role of pet birds in epidemiology of STEC infection should not be underestimated.

\section{REFERENCES}

Adu-Bobie J, Frankel G, Bain C, Goncalves AG, Trabulsi LR, Douce G, Knutton S, Dougan G. Detection of intimins alpha, beta, gamma, and delta, four intimin derivatives expressed by attaching and effacing microbial pathogens. Journal of Clinical Microbiology 1998;36:662668.

Askari Badouei M, Zahraei Salehi T, Koochakzadeh A, Kalantari A, Tabatabaei S. Molecular characterization, genetic diversity, and antibacterial susceptibility of Escherichia coli encoding Shiga toxin $2 \mathrm{f}$ in domestic pigeons. Letters in Applied Microbiology 2014;59(4):370-6 doi:10.1111/lam.12288

Beutin L, Geier D, Zimmermann S, Karch H. Virulence markers of Shiga-like toxin-producing Escherichia coli strains originating from healthy domestic animals of different species. Journal of Clinical Microbiology 1995;33:631-635

Farooq S, Hussain I, Mir MA, Bhat MA, Wani SA. Isolation of atypical enteropathogenic Escherichia coli and Shiga toxin 1 and 2f-producing Escherichia coli from avian species in India. Letters in Applied Microbiology 2009;48:692-697.

Feng PCH, Jinneman K, Scheutz F, Monday S. Specificity of PCR and serological assays in the detection of Escherichia coli Shiga toxin subtypes. Applied and Environmental Microbiology 2011; 77:66996702

Friesema I, van der Zwaluw K, Schuurman T, Kooistra-Smid M, Franz E, van Duynhoven $Y$, van Pelt W. Emergence of Escherichia coli encoding Shiga toxin $2 f$ in human Shiga toxin-producing $E$. coli (STEC) infections in the Netherlands, January 2008 to December 2011. Eurosurveillance 2014;19: 20787. Available from: http://www.eurosurveillance.org/ ViewArticle.aspx? Articleld=20787.

Ghanbarpour R, Sami M, Salehi M, Ouromiei M. Phylogenetic background and virulence genes of Escherichia coli isolates from colisepticemic and healthy broiler chickens in Iran. Tropical Animal Health and Production 2011:43:153-157.

Grossmann K, Weniger B, Baljer G, Brening B, Wieler LH. Racing, ornamental and city pigeons carry Shiga toxin-producing Escherichia coli (STEC) with different Shiga toxin subtypes, urging further analysis of their epidemiological role in the spread of STEC. Berliner und Münchener Tierärztliche Wochenschrift 2005;118:456-463.

Gyles CL. Shiga toxin-producing Escherichia coli: an overview. Journal of Animal Science 2007;85: 45-62.

Isobe J, Kimata K, Shimojima M, Hosorogi S, Tanaka D, Gyobu Y. Isolation of Escherichia coli 0128:HNM harboring stx2f gene from diarrhea patients. Kansenshogaku Zasshi 2004;78:1000-1005.

Kobayashi H, Kanazaki M, Hata E, Kubo M. Prevalence and characteristics of eae- and stx-positive strains of Escherichia coli from wild birds in the immediate environment of Tokyo Bay. Applied and Environmental Microbiology 2009;75:292-295

Kobayashi H, Pohojanvirta T, Pelkonen S. Prevalence and characteristics of intimin- and Shiga toxin-producing Escherichia coli from gulls, pigeons and broilers in Finland. Journal of Veterinary Medical Science 2002;64:1071-1073.

Law D. Virulence factors of enteropathogenic Escherichiacoli. Journal of Medical Microbiology1988; 26:1-10.

Lin Z, Kurazono $\mathrm{H}$, Yamasaki S. Takeda Y. Detection of various variant verotoxin genes in Escherichia coli by polymerase chain reaction. Microbiology and Immunology 1993;37:543-548.

Morabito S, Dell'Omo G, Agrimi U, Schmidt H, Karch H, Cheasty T, Caprioli A. Detection and characterization of Shiga toxin-producing Escherichia coli in feral pigeons. Veterinary Microbiology 2001;82:275-283.

Norazah A, Rahizan I, Zainuldin T, Rohani MY, Kamel AG. Enteropathogenic Escherichia coli in raw and cooked food. Southeast Asian Journal of Tropical Medicine and Public Health 1998;29:91-93.

O'Brien $A D$, Tesh VL, Rolfe AD. Shiga toxin: biochemistry, genetics, mode of action, and role in pathogenesis. Current Topics in Microbiology and Immunology 1992;180: 65-94. 
Koochakzadeh A, Askari Badouei M,

Zahraei Salehi T, Aghasharif S,

Soltani M, Ehsan MR
Prevalence of Shiga Toxin-Producing and Enteropathogenic Escherichia coli in Wild and Pet Birds in Iran
Oh JY, Kang MS, Hwang HT, An BK, Kwon JH, Kwon YK. Epidemiological investigation of eaeA-Positive Escherichia coli and Escherichia albertii strains isolated from healthy wild birds. Journal of Microbiology 2011;49:747-752.

Paton AW, Paton JC. Detection and characterization of shiga toxigenic Escherichia coli by using Multiplex PCR assays for stx1, stx2, eaeA, EnterohemorrhagicE. coli hlyA, rfb 0111 and rfbO157. Journal of Clinical Microbiology 1998;36:598-602.

Prager R, Fruth A, Siewert U, Strutz U, Tschape H. Escherichia coli encoding Shiga toxin $2 \mathrm{f}$ as an emerging human pathogen. International Journal of Medical Microbiology 2009;229:343-353.

Quinn PJ, Markey BK, Leonard FC, Fitzpatrick ES, Fanning S, Hartigan PJ. Veterinary microbiology and microbial disease. 2nd ed. London: Mosby-Year book Europe; 2011.

Schmidt H, Plaschke B, Franke S, Russmann H, Schwarzkopf A, Heesemann $\mathrm{J}$, Karch $\mathrm{H}$. Differentiation in virulence patterns of Escherichia coli possessing eae genes. Medical Microbiology and Immunology 1994;183:23-31.

Schmidt H, Scheef J, Morabito S, Caprioli A, Wieler LH, Karch H. A new Shiga toxin 2 variant (Stx2f) from Escherichia coli isolated from pigeons. Applied and Environmental Microbiology 2000;66:1205-1208.
Wani SA, Samanta I, Bhat MA, Nishikawa Y. Investigation of Shiga toxinproducing Escherichia coli in avian species in India. Letters in Applied Microbiology 2004;39:389-394

Wen-Jie J, Zhi-Ming Z, Yong-Zhi Z, Ai-Jian Q, Hong-Xia S, Yue-Long L, Jiao W, Qian-Qian W. Distribution of Virulence-Associated Genes of Avian Pathogenic Escherichiacoli Isolates in China. Agricultural Sciences in China 2008;7:1511-1515.

Zahraei Salehi T, Askari Badouei M, Mehdizadeh Gohari I. Molecular detection and antibacterial susceptibility of enteropathogenic Escherichia coli (EPEC) and shigatoxigenic Escherichia coli (STEC) strains isolated from healthy and diarrhoeic dogs. Comparative Clinical Pathology 2011;20:585-589.

Zahraei Salehi T, Safarchi A, Peighambari SM, Mahzounieh M, Rabbani Khorasgani M. Detection of stx1, stx2, eae, espB and hly genes in avian pathogenic Escherichia coli by multiplex polymerase chain reaction. Journal of Veterinary Research 2007;62:37-42.

Ziebell KA, Read SC, Johnson RP, Gyles CL. Evaluation of PCR and PCRRFLP protocols for identifying Shiga toxins. Research in Microbiology 2002;153:289-300. 